the tunnel is advancing towards the Comstock at the rate of
ten feet per day, and in a few months will enter the formation ten feet per day, and in a few months will enter the formation
in which lies the great lode. Some facts regarding it will, therefore, not be amiss. which washes the eastern base of the Washoe Range, in
which the Comstock lies. It has been driven a total distans has recourse to in making his cannon. When he has hun and chilled it he proceeds to dilate the bore
of 17,000 feet up to date, and is progressing at the rate of 300 . Wedges of steel, shaped in the form of cones, are forced i which the Comstock lies. It has been driven a total distance has cast his gun and chilled it he proceeds to dilate the bore.
of 17,000 feet up to date, and is progressing at the rate of $300 \mid$ Wedges of steel, shaped in the form of cones, are forced in
feet per month. Not more than 2,800 feet now intervenes the tube of the gun one after another, until the calibre of
between the breast and the nearest nine on the Comstock, the weapon has been increased by something like 7 or 8 per between the breast and the nearest nine on the Comstock,
the Savage, so that, if the present rate of progression were the Savage, so that, if the present rate of progression were
maintained, about ten months more will suffice to complete the connection. The lode will be cut at a deptl of about
1,800 feet perpendicularly below the surface, and very nearly the center, measuring by the extcnt of the surf ce workings.
It is then proposed, eitler by the Sutro Company combination of owners along the vein, to run a drift north and south through each claim until the ends of the vein
laterally are reached. This will connect every mine on the
vein with the tunnel; will drain the entire workings; and, should these lateral drifts be put under one management and made a common highway, will afford the means of working
the entire vein through one opening. It is now about cight years since work was first begun at
the town of Sutro, on the Carson River. The cxpense of the town of Sutro, on the Carson River. The cxpense of
prosecuting the work has averaged about $\$ 1,000$ per day, and when the Comstock is reachcd the total cost will have
amounted to about $\$ 3,000,000$. The tunnel is double-
tracked, as straight as an arrow in its course, with a rise just tracked, as straight as an arrow in its course, with a rise just along its course.
At the moutl of the tunnel the Sutro Company have laid out a town, have secured magnificent water-powers, and ex-
pect to realize largely on that part of thcir investment by pect to realize largely on that part of their investment by
the removal of most of the mining and milling operations on the vein from Virginia City to the Carson.
The fear has been expressed of late that, when the soft and yielding formation in which the lode lies is reached, great difficulties will be found in keeping open the tunnel;
that the strongest of timbering, and cven masonry, will be
unable to withstand the enormous pressure. The trouble Mr. Sutro confidently expects to overcome. Already several ore
cliannels liave been crossed in penetrating so farinto Washoe overcome completely.

There are now many rumors afloat pointing to the con-
solidation of interests between the Tunnel Company an some of the more prominent mines. The indomitable will and energy of Mr. Sutro have overcome, one by onc, each and every obstacle placed in his way by those who opposed
his enterprise; there is hardly a chance that, in the hour of his success, he will submit to anything short of a controlling interest in his work. When the vein is at last reached, and
the immense benefits that it certainly will bring to all the mines shown, it is very doubtful if the belligerent owners who have all along threatened to control the rights of the
tunnel will attempt to injure its usefulness or refuse to

THE UCHATIUS GUN.

OF all the Powers, it is curiously enough steaciy-going Austria which has talsen the boldest and most independent
course in the matter of artillery. It was but at the end of 1875 that the Austrian War Office decided to adopt the Uchatius cannon for field artillery, and yet at this moment every armed with the new weapon. Within eighteen montls no and now the Vicnna arsenal is engaged in the nanufacture
of heavy guns of the same character. Never was a more encryetic step taken. A new cannon of some sort was held army, and a commission having becn intrusted with the selection of an arm, pronounced without delay in favor of the scheme brought forward by General von Uchatius. In Ocand twelve months afterwards a sweeping reform, which an expenditure of $£ 1,800,000$, to be spent in two years, and General von Uchatius was directed to give all the assistance
in his power toward the fulfillment of the design. The Uchatius gun is made of so-called steel-bronze. Chilled bronze would be a better name, since Uchatius casts his metal in a
chilled, or metal mould, in tlie same manner, pretty well, as Bronze, as everybody knows, has been a favorite metal with gun-founders from the earliest days, and in the East, especially nuagnificent castings of this nature have been produced. About 90 per cent. of copper and 10 of tin is the mixture com.
monly cmployed in making ordinary bronze, but 8 per cent. of tin is the proportion preferred by Uchatius. The diffi-
culty in casting bronzc, as those who have any experience cles of tin becoming isolated in the mass, and giving rise to the defect known as "tin-pitting." Whether we have lost the secret of bronze-casting, or whether in former times they
were more skillful at the work, certain it is that founders of the present day are unable to secure so uniform an alloy ten years ago our own Government adopted, for a brief time, ten years ago our own Government adopted, for a brief time,
bronze artiltery. The addition of a small percentage of phosphorus did not mend matters, and the highest authorities on the subject were at a loss to suggest an effective
remedy. Our bronze guns, too, had another defect which could not be overcome. After firing the bore became affected, nd the weapon, as it was termed, "drooped at the to the abandonment of the bronze gun in this country, and
they are, too, the difficultics which General von Uchatius ap-, pears to have overcome. He has got rid of "tin-pitting," and his guns do not "droop at the muzzle." Uchatius found pressure, he was cnabled to secure a perfectly homogeneous mass, a result which was also furnished, he discovered, the same way as the toughened glass, of which we have heard so much lately. After being cast in a mould, the alloy is thrust into a reservoir of oil, heated to a high temperature, so that
the metal suddenly cools but only down to a certain point. the metal suddenly cools, but only down to a certain point. gradually. A regular and crystallinc structure is in this way
produced, which has none of the defects of ordinary bronze. produced, which has none of the defects of ordinary bronze. As the compressors approach one another the head can pass
$\mathrm{f}_{t}$ is a moot point whether phosphorus cnters into the com-, no further into the barrel, being held at the corners $\mathbf{M}$ and
position at all. Chemists tell us they can find no trace of it, $\mathbf{N}$. The action of the spring now begins, and the head be position at all. Chemists tell us they can find no trace of it, $\mid N$. The action of the spring now begins, and the head be-
but this is no absolute proof that a small percentage of the $\mid$ ing held firmly in position against the ends of the inner The inventor is rather reticent on the point, but in any case eous alloy of a hard crystalline nature. One other expedient the effect of hardening or or steeling the core, but also of rendering the gun more elastic and capable of resisting more The gun, after this process, is in a state of elastic tension, equal to that which was exerted to dilate the gun in the first
instance; and that this is actually the case can scarcely be oubted, since it is a fact that a section of the gun, before
eing quite severed, will tear itsclf loose with considerable
violence, and will be found on separation to have partially violence, and will be found on separation to have partially
returned to its former calibre. So far as practicable trials returned to its former calibre. So far as practicable trials gun, which compares favorably with the Krupp the Ucel cannon
in the matter of accuracy and durability; wlile as regards n the matter of accuracy and durability ; wlile as regards
is cost, it is far cheaper than any other rifled ordnance. A steel field-piece costs upwards of $£ 100$, even when not
protected with rings, while the iron steel weapon manufacprotected with rings, while the iron steel weapon manufac-
ured in this country costs about £70 sterling; the steel
bronze cannon of General von Uchatius, on the other hand, are made for £35 apiece. In construction, the Austrian gun atter claimed compensation for an infringement of hi patent when the manufacture of the Uchatius gun was firs
commenced. The Essen works, our readers may know, sup ply not only Germany with steel breech-loaders, but have
provided the present belligerents with all their modern artilprovided the present belligerents with all their modern artil-
lery. Russia has still many brass cannon on hand, and Tur-
key a guodly number of Armstrongs, but both Powers mainly key a guodly number of Armstrongs, but both Powers mainly army in such good stead during the last war that their repu-
tation is firmly established. They are of crucible steel, and tation is firmly established. They are of crucible steel, and
the breech, instead of being upon a linge, or in the form of being further prevented by rings of phosplor-copper.

\section{IMPROVEMENT IN THE MANUFACTURE OF}

By Ralpi M. Munroe, Edgewater, N. Y.

LET us suppose the two cylinders of wood, $\mathrm{D}$ and $\mathrm{E}$, on Within the other, to have been placed in position while the
orming and compressing parts of the machine $O$ and $P$ were further apart, so that the ends of the barrel-cylinde
would rest in a part of the compressing die which has greater diameter than the end of the barrel. As the com
pressors approach each other, the sides are contracted and he barrel shape given to the cylinder. In order that the

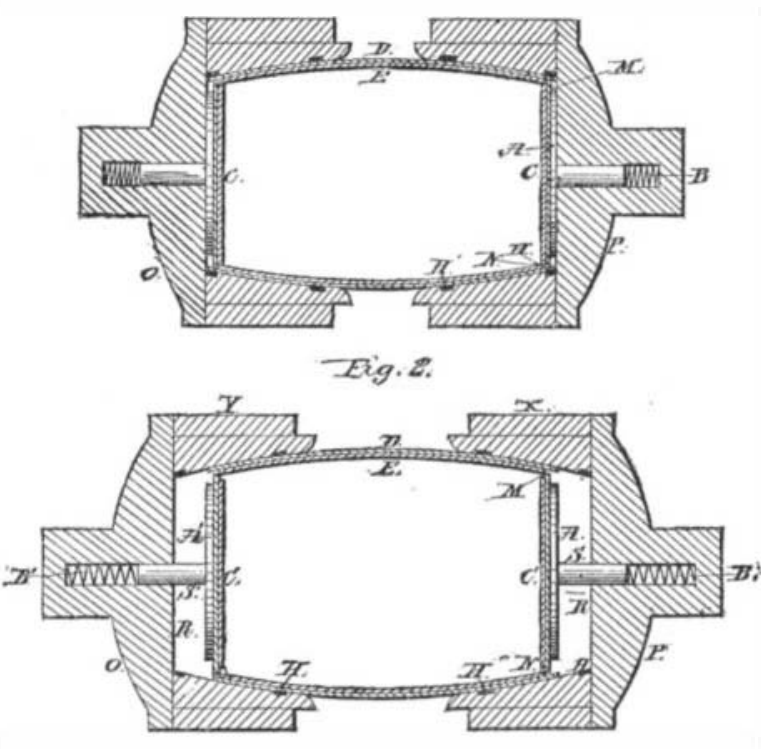

head shall be in such a position that the contracting ends of ntinue their movement into the compressors and close rmly upon it, I place in the compressing or forming part

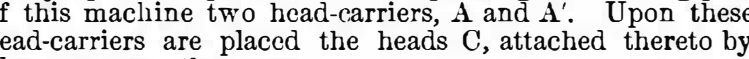
These head.carriers ay.

tirmly fastened to the moving position that it is grasped by the incoming barrel-sides. holder yields to the forward motion of the barrel or of the y mechanical

Now, let us suppose the machine to be operated and the compressors to approach; the sides of the barrel, as they are order that they may accomplish this readily, and may easily place betwcen them some oil or lubricating substance, or wood to move freely over the other.

Now the position of the bead C, held upon the holder A, f the barrel approach one another, the inner barrel $\mathrm{E}$ will pass inside the countersunk outer head M, so that the two the compressors approach one another the head can pass compressors, but are carried by shafts $\mathrm{S}$ and $\mathrm{S}^{\prime}$, controlled
by springs $\mathrm{B}$ and $\mathrm{B}^{\prime}$. This movable head-holder performs machincs, and thus it forces the inner barrel to assume compressed in the die, move one over the other, in order to
ssume their compressed condition, as shown in Fig. 1 . In and the sides of the barrel, is such that, as the sides or ends

element was not originally contained in the alloy, being burnt $\mathrm{keg}$, or the barrel $\mathrm{E}$, the machine continues to compress
out after it had done its work of harmonizing the two metals. the sides until they embrace and hold firmly in their dove-

tailed recess the heads of the birre.

Hoops $\mathrm{H} \mathrm{H}$ H, etc., are placed in recesses in the compreshave completed their movement, the head-carriers A A bring up against the sides $\mathrm{R}$ of the compressors at both
cnds. The result of this is, that the inner barrel is now moved one way or the other, so as to register and coincide
with the outer barrel, being pressed in equally from both ends by the carriers $A$ and $A^{\prime}$, which are of equal width. same time the heads, being firmly in, are enobraced by the contraction of the barrel, so that they can neither be
moved in nor out. One half, usually the upper half, of both compressors is made movable, as at $x$ and $y$, so that on comhinge, leaves the hoops behind. The barrel is then removed therds the barrel is taken from this machine complete in all Tespects.

The amount of lubricating material used in forming be sufficient to fill all determined by experiment, so as to be sufficient to fill all intcrstices and cracks in the barrel,
and to allow the passage, one over the other, of the moving parts. It is evidently very important that the countersunk barrel itself.

In the manufacture of barrels which are to contain petroeum, I use a glue which is insoluble in it, and thus make a

ON THE PRIMING OF STEAM BOILERS. By Mr. Willias MaJor, Engineer, Danish Royal Navy.* Some time since the author read a long article in an engineering publication on the boiler fatalitics on board her
Majesty's transport ship Serapis, on her voyage out to India with the Prince of Wales. The substance of that article was that the engincering profession was still ignorant of the certainly humiliating for the protession to be obliged to admit that one hundred years after the introduction of the rally experienced as the priming of steam boilers; yet such is the case, as proved by the Serapis. The first question to and until this question is satisfactorily answered cngineer will still go on devising mechanical contrivances for obviatsitherto. If we ask a practical engineer what the cause of priming is, we gencrally have dirty watcr assigned as
rcason, and a specific is given for its prevention; or, more usual, since the more general introduction of highpressure steam boilers, some remarks not very complimentary harge and the priming of which he is unable to master. I we ask the same question of a scientific man - a professor of lition caused by the action of heat on the body of water contained in the boiler, but he is not quite certain as to whether this so-called ebullition is a chemical or a mechanical action. With this meagre information the profession has
had to content itself, enduring at the same time all the evils attendant thereon.
In the case of the Serapis we have a ship engined with power sufficient to propel her through the water with a speed
of 13 knots an hour but that engine power was so paralyzed through the priming of the boilers that her speed was reduced to 9 knots. The case of the Serapis is by no means exceptional, the same evil obtains in a greater or less degree on
board every steamship afloat, and the introduction of highpressure steam together with the surface condenser has very arge bodies of water passing with the steam from the boilers more valuable steam engines are destroyed from this cause than from all other causes put together. The author need not enlarge further on the subject of priming and its conse-
quences, but will observe that he feels assured of having discovered a better theory for the cause of priming in steam
boilers than is yet generally known. He has also found a practical means of preventing the eril, and that too withou putting shipowners to any expense, but on the contrary,
since to stop priming is to save fuel. The author does not propose any costly or complicated maclinery for the pur-
pose of preventing priming, not even a wooden deck placed In the boiler, as it was stated was adopted in the Serapis
boilers. As bcfore stated, the cause of priming is said to be y the heat acting on the water. The author is bold enoug o alter the word "ebullition"; into the more intelligible word "friction," and he ventures to assert that priming in

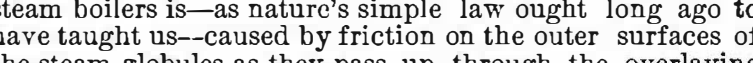
the steam globules as they pass up through the overlaying
body of water into the steam chest, the amount of such they pass through the body of water, and also depending
upon the state of the water as regards its purity. In other ords, the friction is least when the water is pure-distilled -while it is the greatest when the water is charged with all The author is only now, after four years' practical experiance on a large scale, publicly making the above assertion,
and with the full conviction of its correctness. Having satisfied himself as to the feasibility of the friction
heory, it occurred to him that we had mistaken the real effects or action of the old-fashioned system of injecting
melted tallow into boilers for stopping their priming. The reason generally given why tallow or other fatty matter stops
priming is because it spreads itself over the surface of the priming is because it spreads itself over the surface of the
water and quiets it. The author, however, does not believe his is the case, since whenever there is a pressure of steam fuses itself throughout the whole contents of the boiler, both water and steam. That this is the case can be proved by boiler charged with tallow or by condensing a portion of the steam. Both the taste and smell of tallow will be found priming by lubricating the globules of steam as they pass hrough the overlaying body of water, reducing the friction their surfaces, and, as a natural consequence, causing n as we continue to supply a boiler with a sufficient quan- 